University of Nebraska - Lincoln

DigitalCommons@University of Nebraska - Lincoln

2013

\title{
A prospective study of physical fitness, obesity, and the subsequent risk of mental disorders among healthy young adults in army training
}

\author{
Marlene E. Gubata \\ Walter Reed Army Institute of Research, Marlene.Gubata@us.army.mil \\ Nadia Urban \\ Walter Reed Army Institute of Research \\ David N. Cowan \\ Walter Reed Army Institute of Research \\ David W. Niebuhr \\ Walter Reed Army Institute of Research
}

Follow this and additional works at: https://digitalcommons.unl.edu/usarmyresearch

Gubata, Marlene E.; Urban, Nadia; Cowan, David N.; and Niebuhr, David W., "A prospective study of physical fitness, obesity, and the subsequent risk of mental disorders among healthy young adults in army training" (2013). US Army Research. 197.

https://digitalcommons.unl.edu/usarmyresearch/197

This Article is brought to you for free and open access by the U.S. Department of Defense at DigitalCommons@University of Nebraska - Lincoln. It has been accepted for inclusion in US Army Research by an authorized administrator of DigitalCommons@University of Nebraska - Lincoln. 


\title{
A prospective study of physical fitness, obesity, and the subsequent risk of mental disorders among healthy young adults in army training
}

\author{
Marlene E. Gubata ${ }^{\mathrm{a}, *}$, Nadia Urban ${ }^{\mathrm{a}, \mathrm{b}}$, David N. Cowan ${ }^{\mathrm{a}, \mathrm{b}}$, David W. Niebuhr ${ }^{\text {a }}$ \\ a Department of Epidemiology, Preventive Medicine Branch, Walter Reed Army Institute of Research, 503 Robert Grant Road, Silver Spring, MD 20910, United States \\ b Allied Technology Group, Inc., 1803 Research Boulevard, Suite 601, Rockville, MD 20850, United States
}

\section{A R T I C L E I N F O}

\section{Article history:}

Received 18 September 2012

Received in revised form 3 April 2013

Accepted 9 April 2013

\section{Keywords:}

Mental disorders

Obesity

Physical fitness

Screening

\begin{abstract}
A B S T R A C T
Objective: Mental health disorders contribute substantially to medical and occupational morbidity. The role of fitness and physical activity in the prevention of mental health disorders is not well established, but epidemiologic data suggest that physical activity can protect against anxiety and depression.

Method: The analyses presented in this report, from a prospective cohort study, evaluate the association between fitness (as measured by a 5-minute step test), and being overweight (defined as exceeding weight and body fat allowances) at military entrance, with subsequent onset of mental disorder diagnosis in the first year of service. The association between risk factors and mental disorder diagnosis was analyzed using multivariate Poisson regression with the adjusted incidence rate ratio (aIRR) as the measure of association.

Results: Among weight-qualified participants, factors associated with increased incidence of mental disorder included failing the physical fitness test (aIRR: 1.36, p $<0.0001$ ), female sex (aIRR: 2.17, p $<0.0001$ ), and smoking (aIRR: $1.49, \mathrm{p}<0.0001$ ). Among fit participants, being overweight was not significantly associated with mental disorder (aIRR: $1.11, \mathrm{p}=0.1540$ ).

Conclusions: This test has potential military utility as an adjunct part of the medical examination process. Additional research is needed among civilians to determine if similar associations exist. If so, intervention studies should be conducted to determine if improving physical fitness reduces subsequent psychiatric disorder risk, particularly among young adults entering into stressful situations.
\end{abstract}

Published by Elsevier Inc.

\section{Introduction}

Nearly half of U.S. adults are diagnosed with mental disorders in their lifetime [1]. Multiple adverse occupational outcomes, including absenteeism, reduced productivity, unemployment, disability and high health care utilization, have been linked to mental disorders [2-5]. In the U.S. military, mental disorders are the most common cause of hospitalizations among military men and second among women (following normal delivery) [6], and are associated with subsequent discharge from service for medical disability, misconduct/ legal problems, and unauthorized work absences [7-9]. In addition, military recruits who report a history of a mental health diagnosis generally require a medical waiver prior to entrance into service [10].

The role of exercise and physical activity in the prevention of mental disorders is not well established, but epidemiologic studies suggest that physical activity can protect against symptoms of anxiety and depression [11-13], and prevent the development of these disorders [12-14]. Preliminary data indicates that exercise added to traditional mental disorder treatment regimens reduces symptoms and

\footnotetext{
Previous presentation: none.

* Corresponding author. Tel.: +1 301319 9583; fax: +1 3013199104

E-mail address: Marlene.Gubata@us.army.mil (M.E. Gubata).
}

improves function [12-14] and helps treat anxiety in patients with chronic diseases [13]. Regular exercise is commonly recommended as an adjunct mental disorder treatment modality based on expert consensus [13], but without uniform guidelines for implementation [12]. These studies relied heavily on self-reported physical activity in their measurement. The literature is less complete regarding the association between measured physical fitness and mental health. However, if exercise is a pathway towards physical fitness, then directly measured physical fitness may be an important area of study without reliance on self-reported activity, which is susceptible to over- or underreporting [15].

Obesity has been found to be associated with psychiatric disorders in various studies [16-24]. Specifically, obesity has been observed to be associated with an increased risk of mood and anxiety disorders in several cross-sectional studies [16-18,21]. Some longitudinal studies found an increased risk of incident depressive disorders among the overweight or obese [19,21-23]. However, two prospective studies found no association $[19,24]$ or a negative association between overweight or obese and anxiety disorders [23]. Kasen et al., 2008 did find a positive association between obesity and overweight and generalized anxiety disorder, but the association among the overweight disappeared after adjustment for other significant risk factors. Analysis of the relationship between obesity and substance use disorders has 
yielded conflicting results [16-20,23,24]. Longitudinal studies found either no association [23,24] or a negative association between overweight/obese and substance abuse disorders [19]. However, none of the epidemiologic research examining obesity and mental disorders measured or controlled for fitness in study participants [16-24].

The analyses presented in this report, utilizing existing data from a previously conducted prospective cohort study, evaluate the association between fitness (as measured by a 5-minute step test), and being overweight or obese (defined as exceeding weight and body fat allowances) at military entrance, with subsequent onset of mental disorder diagnosis in the first year of service. Analyses controlled for sex, smoking and education. This study aims to add to the literature assessing measured physical fitness and overweight/obesity as predictors of mental disorders. Because physical fitness is required and measured during military service [25] and both mental disorders and obesity are generally medically disqualifying for service [26], this study is designed to examine the potentially complex relationship between fitness, obesity and new-onset mental disorders in a military recruit population.

\section{Methods}

These analyses, from a prospective cohort study of U.S. Army trainees, were conducted to determine whether fitness, measured by performance on a step test is associated with mental disorder diagnosis in the first year of service. As part of a secondary analysis, the association between exceeding body fat standards and mental disorder diagnosis was evaluated among those who passed the step test. This study was approved by the Walter Reed Army Institute of Research Institutional Review Board. Data sources and methods have been previously described [27-33].

\section{ARMS fitness test}

In 2004 the U.S. Army Accessions Command directed that all Army applicants at six Military Entrance Processing Stations (MEPS) take a physical fitness test that included a minimum number of pushups and a 5-minute step test. The Assessment of Recruit Motivation and Strength (ARMS) study was implemented at these MEPS between February 2005 and September 2006.

The ARMS fitness test included a 5-minute modified Harvard Step Test [34-39] to a cadence of 120 beats per minute at a step height of 16 in. for males and $12 \mathrm{in.} \mathrm{for} \mathrm{females,} \mathrm{and} \mathrm{number} \mathrm{of} \mathrm{push-ups} \mathrm{com-}$ pleted within one minute. A complete step was defined as stepping up on the platform with both feet and stepping down on the floor. Accordingly, 120 beats per minute corresponded to 30 steps per minute. Passing the step test was defined as completing the step test for five minutes at the proper pace. For this study only step test results were considered because less than $4 \%$ of subjects failed the pushups.

Applicants meeting a two-tiered screen for accession weight and body fat standards for their gender-specific height and age group were 'weight qualified' (WQ) [25]. Applicants exceeding weight-forheight and body fat percent standards, up to $30 \%$ for men and $36 \%$ for women, (limit set to the maximum allowable to subjects greater than or equal to 40 years) as defined in Army Regulation 40-501 were 'exceeds body fat' (EBF) [25]. Body fat percentage was measured using circumference taping methodology as outlined in Army Regulation 600-9, The Army Weight Control Program [10]. For men, neck and waist circumferences were measured and for women, neck, waist, and hip circumferences were measured, then compared with allowed body fat percentages tabularized in the Army regulation [10]. EBF subjects were required to pass the step test before being allowed to enlist. Upon passing the step test, they were granted a waiver for accession into the Army. While WQ applicants were required to take the test, the results did not impact their ability to enlist.

\section{Study population}

Study subjects included U.S. Army active duty members who completed the step test and entered the military for the first time between February 2005 and September 2006. After complete description of the study to the subjects, written informed consent was obtained. Subjects were at least 18 years of age and followed for one year after entry into service. Excluded individuals included those with no valid weight, height, or date of birth recorded $(\mathrm{N}=8)$ or EBF subjects who failed the step test but entered the Army at a later time $(\mathrm{N}=9)$. Individuals with neither an ambulatory health care record in a military medical treatment facility or a matching accession date within 30 days of the ARMS study entry date were also excluded $(\mathrm{N}=82)$.

\section{Data sources}

\section{Accession}

Individuals who completed the step test and met inclusion and exclusion criteria were selected $(\mathrm{N}=11,369)$ and matched to accession data provided by the Center for Accession Research, U.S. Army Accession Command. The U.S. Military Entrance Processing and the Defense Manpower Data Center provided other enlistment data, including education level and the Armed Forces Qualification Test (AFQT) percentile score (a math and verbal cognitive test score).

\section{Morbidity}

The Patient Administration Systems and Biostatistics Activity provided ambulatory health care encounter data from the Standard Ambulatory Data Record for all visits at military treatment facilities. Mental disorder incident cases were defined as at least one ambulatory encounter resulting in any diagnosis with International Classification of Diseases, Ninth Revision (ICD-9) codes between 290 and 319 in any diagnosis position, excluding 305.1 (tobacco use disorder). Mental disorders were divided into the following diagnostic categories, reflecting Diagnostic and Statistical Manual of Mental Disorders, Fourth Edition grouping [7]: adjustment disorders, substance use disorders, mood disorders, anxiety disorders, personality disorders, psychoses, somatoform disorders, and other non-psychotic conditions. Major depression disorder (ICD-9 codes: 296.2, 296.3), as a subset of the more general mood disorder category, was further analyzed as a distinct outcome.

\section{Statistical analysis}

In the primary analysis, physical fitness which was determined by performance on the step test (pass/fail) was analyzed as a predictor of mental disorder diagnosis. In this analysis, only subjects meeting weight-for-height and body fat standards (WQ) were included. In the secondary analysis, EBF status was analyzed as a predictor of mental disorder diagnosis, comparing EBF subjects granted an accession waiver and WQ subjects who had passed the step test.

All mental disorder diagnoses occurring within the first year of service were counted. With the exception of major depression, which was included as a subset of the mood category and evaluated separately, all mental disorder categories were mutually exclusive (i.e., each diagnostic code appears in only one category). However, a study subject may be included in more than one disorder category if $\mathrm{s} /$ he was diagnosed with disorders from more than one category. Only individuals who did not have any mental disorder diagnoses were compared with cases in each specific mental disorder category.

Chi-square and Fisher's exact tests were used to describe categorical data. Crude incidence rates (IR) of outcomes were defined as the number of cases per 1000 person-days of military service. Person-time accrued until the first mental disorder medical encounter or the individual left the Army. Crude and adjusted incidence rate ratios (IRRs) were calculated using Poisson regression for all outcomes. Variables in the regression models included step test result, body fat status (i.e., EBF vs. WQ), sex, age, body mass index (BMI), smoking status, education and AFQT score. 
Age categories (18-19 years, 20-24 years and 25 years and over) were used based on results from previous ARMS studies which showed increased risk of musculoskeletal injuries and stress fractures by age group $[24,27,28]$. AFQT scores were divided into percentile categories which are used by the military to determine eligibility for enlistment [40]. Normal weight was defined as BMI $<25 \mathrm{~kg} / \mathrm{m}^{2}$, overweight as BMI 25 to $30 \mathrm{~kg} / \mathrm{m}^{2}$ and obesity as BMI $>30 \mathrm{~kg} / \mathrm{m}^{2}$ according to the classification system outlined by the Centers for Disease Control [41]. However, BMI and body fat status were not used in the same regression model. Potential confounders included in all multivariable analyses included sex, smoking status and education. All statistical analyses were performed using SAS version 9.2 (SAS Institute, Cary, NC).

Results

Demographics

There were 10,216 weight-qualified and 1153 EBF study participants (Table 1). Among WQ participants, all reported and measured characteristics differed significantly between the step test passers and step test failers. Among those who passed the step test, sex, smoking status, BMI, education, and AFQT score differed significantly between WQ and EBF groups. Obese subjects accounted for $17.3 \%$ (1970) of the study population; mean BMI of this category was $32.8 \pm 2.1 \mathrm{~kg} / \mathrm{m}^{2}$.

Mental disorder diagnosis

There were 2295 cases with at least one mental disorder diagnosis. Table 2 summarizes counts and percentages for specific mental disorder diagnostic categories. The most common diagnoses were adjustment disorder, mood disorder, substance abuse and anxiety disorder.

Table 1

Characteristics of ARMS study participants $(\mathrm{N}=11,369)$

\begin{tabular}{|c|c|c|c|c|c|c|c|c|}
\hline \multirow[b]{2}{*}{ Total } & \multicolumn{2}{|c|}{$\begin{array}{l}\text { WQ: } \\
\text { passed } \\
\text { step test }\end{array}$} & \multicolumn{2}{|c|}{$\begin{array}{l}\text { WQ: failed } \\
\text { step test }\end{array}$} & \multirow[t]{2}{*}{$\mathrm{P}^{\mathrm{a}}$} & \multicolumn{2}{|c|}{$\begin{array}{l}\text { EBF: } \\
\text { passed } \\
\text { step test }\end{array}$} & \multirow[t]{2}{*}{$\mathrm{P}^{\mathrm{b}}$} \\
\hline & $\mathrm{N}$ & $\%$ & $\mathrm{~N}$ & $\%$ & & $\mathrm{~N}$ & $\%$ & \\
\hline & \multicolumn{2}{|l|}{7713} & \multicolumn{2}{|l|}{2503} & & \multicolumn{2}{|l|}{1153} & \\
\hline \multicolumn{9}{|l|}{ Sex } \\
\hline Male & 6646 & 86.2 & 1976 & 78.9 & $<0.0001$ & 834 & 72.3 & $<0.0001$ \\
\hline Female & 1067 & 13.8 & 527 & 21.1 & & 319 & 27.7 & \\
\hline \multicolumn{9}{|l|}{ Age (years) } \\
\hline $18-19$ & 3600 & 46.7 & 1045 & 41.7 & $<0.0001$ & 518 & 44.9 & $<0.1290$ \\
\hline $20-24$ & 3161 & 41.0 & 1068 & 42.7 & & 507 & 44.0 & \\
\hline$>25$ & 952 & 12.3 & 390 & 15.6 & & 128 & 11.1 & \\
\hline \multicolumn{9}{|l|}{ Smoker } \\
\hline No & 5661 & 73.4 & 1888 & 75.4 & $<0.0001$ & 899 & 78.0 & $<0.01$ \\
\hline Yes & 1941 & 25.2 & 613 & 24.5 & & 241 & 20.9 & \\
\hline Missing & 111 & 1.4 & 2 & 0.1 & & 13 & 1.1 & \\
\hline \multicolumn{9}{|l|}{$B M I$} \\
\hline $\begin{array}{l}\text { Underweight } \\
\qquad(\mathrm{x}<18.5)\end{array}$ & 282 & 3.7 & 83 & 3.3 & $<0.0001$ & 0 & 0.0 & $<0.0001$ \\
\hline $\begin{array}{l}\text { Normal weight } \\
\qquad(18.5<\mathrm{x}<25)\end{array}$ & 4463 & 57.9 & 1157 & 46.2 & & 23 & 2.0 & \\
\hline $\begin{array}{l}\text { Overweight } \\
\qquad(25<\mathrm{x}<30)\end{array}$ & 2155 & 27.9 & 873 & 34.9 & & 363 & 31.5 & \\
\hline Obese $(>30)$ & 813 & 10.5 & 390 & 15.6 & & 767 & 66.5 & \\
\hline \multicolumn{9}{|l|}{ Education } \\
\hline $\begin{array}{c}\text { HS diploma or } \\
\text { equivalent }\end{array}$ & 7347 & 95.3 & 2424 & 96.8 & $<0.001$ & 1117 & 96.9 & $<0.05$ \\
\hline Bachelor and above & 365 & 4.7 & 79 & 3.2 & & 36 & 3.1 & \\
\hline Unsure/missing & 1 & 0.0 & 0 & 0.0 & & 0 & 0.0 & \\
\hline \multicolumn{9}{|l|}{ AFQT percentile } \\
\hline $65-99$ & 3048 & 39.5 & 865 & 34.6 & $<0.001$ & 428 & 37.1 & $<0.05$ \\
\hline $50-64$ & 1789 & 23.2 & 624 & 24.9 & & 309 & 26.8 & \\
\hline $11-50$ & 2857 & 37.0 & 1007 & 40.2 & & 416 & 36.1 & \\
\hline Unsure/missing & 19 & 0.2 & 7 & 0.3 & & 0 & 0.0 & \\
\hline
\end{tabular}

ARMS, Assessment of Recruit Motivation and Strength; WQ, Weight Qualified; EBF, Excess Body Fat; BMI, Body Mass Index; AFQT, Armed Forces Qualification Test.

a Comparisons made between WQ step test passers and WQ step test failers.

b Comparisons made between WQ step test passers and EBF step test passers.
Table 2

Mental disorder diagnostic categories among weight-qualified and excess body fat subjects

\begin{tabular}{|c|c|c|c|c|c|c|c|c|}
\hline \multirow[t]{2}{*}{ Description } & \multicolumn{2}{|c|}{$\begin{array}{l}\text { WQ: passed } \\
\text { step test } \\
(\mathrm{N}= \\
7713)\end{array}$} & \multicolumn{2}{|c|}{$\begin{array}{l}\text { WQ: failed } \\
\text { step test } \\
(\mathrm{N}= \\
2503)\end{array}$} & \multirow[t]{2}{*}{$\mathrm{P}^{\mathrm{a}}$} & \multirow{2}{*}{\multicolumn{2}{|c|}{$\begin{array}{l}\text { EBF: } \\
\text { passed } \\
\text { step test } \\
(\mathrm{N}= \\
1153)\end{array}$}} & \multirow[t]{2}{*}{$\mathrm{P}^{\mathrm{b}}$} \\
\hline & $\mathrm{N}$ & $\%$ & $\mathrm{~N}$ & $\%$ & & & & \\
\hline Adjustment & 658 & 8.5 & 303 & 12.1 & $<0.0001$ & 133 & 11.5 & $<0.001$ \\
\hline Mood & 381 & 4.9 & 173 & 6.9 & $<0.001$ & 77 & 6.7 & $<0.05$ \\
\hline Substance & 404 & 5.2 & 150 & 6.0 & 0.15 & 47 & 4.1 & 0.09 \\
\hline Anxiety & 184 & 2.4 & 92 & 3.7 & $<0.001$ & 48 & 4.2 & $<0.001$ \\
\hline Personality & 100 & 1.3 & 54 & 2.2 & $<0.01$ & 23 & 2.0 & 0.06 \\
\hline Psychotic & 26 & 0.3 & 11 & 0.4 & 0.46 & 3 & 0.3 & 1.00 \\
\hline Somatoform & 7 & 0.1 & 4 & 0.2 & 0.48 & 4 & 0.3 & $<0.05$ \\
\hline Other & 609 & 7.9 & 291 & 11.6 & $<0.0001$ & 121 & 10.5 & $<0.01$ \\
\hline Major depression ${ }^{\mathrm{C}}$ & 98 & 1.3 & 42 & 1.7 & 0.13 & 20 & 1.7 & 0.20 \\
\hline Any mental disorder & 1430 & 18.5 & 616 & 24.6 & $<0.0001$ & 249 & 21.6 & $<0.05$ \\
\hline
\end{tabular}

a Comparison between weight qualified (WQ) step test passers and weight qualified (WQ) step test failers.

b Comparison between weight qualified (WQ) step test passers and exceeds body fat (EBF) step test passers.

c ICD-9 codes used are subset of mood category.

Physical fitness as predictor of mental disorder diagnosis among weight qualified individuals

There were approximately 3,160,000 person-days of follow-up among WQ subjects yielding 2046 mental disorder cases (Table 3). Failing the step test was significantly associated with mental disorder diagnosis (adjusted IRR: 1.36, 95\% CI: 1.23-1.49). In the multivariable model, sex, smoking status and education were significantly associated with mental disorders. Those with BMI categories of overweight or obese did not have increased incidence. Those who failed the step test had significantly elevated incidence for all but one category of measured mental disorder diagnosis (Fig. 1), highest for personality disorder (adjusted IRR: 1.75, 95\% CI: 1.25-2.44) followed by anxiety disorder (adjusted IRR: $1.57,95 \%$ CI: $1.22-2.01$ ).

Body fat status as predictor of mental disorder diagnosis among fit individuals

There were approximately 2,780,000 person-days of follow-up among subjects who passed the step test, yielding 1103 mental disorder diagnosis cases (Table 4). The crude incidence rate ratio for mental disorder, comparing EBF to WQ was 1.22 (95\% CI: 1.07-1.40). However, body fat status was not significantly associated with mental disorder in the final multivariable model (adjusted IRR: 1.11, 95\% CI: 0.961.27). In the multivariable model, sex, smoking status and education were significantly associated with mental disorders. Multivariable analysis of specific types of mental disorders showed incidence was significantly higher only for adjustment disorders (adjusted IRR: 1.22, 95\% CI: 1.01-1.48) and anxiety disorders (adjusted IRR: 1.54, 95\% CI: $1.12-2.13$ )

\section{Discussion}

In this prospective cohort study of healthy young adults, individuals with poor physical fitness measured by step test failure had 36\% higher incidence of mental disorder diagnosis in the first year of service. These findings were robust in that they were found among both men and women (data not shown). Adjustment disorder diagnosis was the most common mental disorder diagnosis across all study groups. After adjusting for sex, smoking status and education, of the seven specific disorders including the categories other and major depression, unfit individuals had a higher incidence of all but major depression. In the adjusted analysis, recruits who exceeded maximum allowable body fat percentages and were physically fit did not have a significantly higher overall incidence of mental disorders but had increased incidence of anxiety disorders and adjustment disorders. Risk of mental disorder diagnosis was consistently elevated in women and smokers, with decreased risk in those with at least a bachelor's degree.

To the best of our knowledge, this is the first study to document an association between measured physical fitness and subsequent onset of mental disorders. The primary goal of this analysis was to assess measured physical fitness as part of the pre-enlistment medical examination process as a predictor of mental disorder diagnosis. While a significant 
Table 3

Crude and adjusted incidence rate ratios for mental disorder diagnosis among weight-qualified ARMS subjects $(\mathrm{N}=10,216)$

\begin{tabular}{|c|c|c|c|c|c|c|}
\hline & \multirow{2}{*}{$\begin{array}{l}\text { Number } \\
\text { with mental } \\
\text { disorder } \\
\text { diagnosis }\end{array}$} & \multirow{2}{*}{$\begin{array}{l}1000 \\
\text { person-days }\end{array}$} & \multicolumn{2}{|c|}{ Crude IRR } & \multicolumn{2}{|c|}{ Adjusted $^{\mathrm{a}}$ IRR } \\
\hline & & & Value & $95 \% \mathrm{CI}$ & Value & $95 \% \mathrm{CI}$ \\
\hline \multicolumn{7}{|l|}{ Step test status } \\
\hline Pass & 1430 & 2433.4 & REF & & REF & \\
\hline Fail & 616 & 731.4 & 1.43 & $1.30-1.58$ & 1.36 & $1.23-1.49$ \\
\hline \multicolumn{7}{|l|}{ Sex } \\
\hline Male & 1530 & 2733.0 & REF & & REF & \\
\hline Female & 516 & 431.7 & 2.13 & $1.93-2.36$ & 2.17 & $1.97-2.40$ \\
\hline \multicolumn{7}{|l|}{ BMI } \\
\hline Underweight & 78 & 109.4 & 1.06 & $0.85-1.34$ & & \\
\hline Normal & 1167 & 1741.9 & REF & & & \\
\hline Overweight & 570 & 943.6 & 0.90 & $0.82-1.00$ & & \\
\hline Obese & 231 & 369.8 & 0.93 & $0.81-1.07$ & & \\
\hline \multicolumn{7}{|l|}{ Age (years) } \\
\hline $18-19$ & 944 & 1451.2 & REF & & & \\
\hline $20-24$ & 835 & 1304.4 & 0.98 & $0.90-1.08$ & & \\
\hline$\geq 25$ & 267 & 409.1 & 1.00 & $0.88-1.15$ & & \\
\hline \multicolumn{7}{|l|}{ Smoker } \\
\hline No & 1389 & 2361.1 & REF & & REF & \\
\hline Yes & 642 & 767.0 & 1.42 & $1.30-1.56$ & 1.49 & $1.36-1.64$ \\
\hline \multicolumn{7}{|l|}{ Education } \\
\hline $\begin{array}{l}\text { HS Diploma } \\
\text { and } \\
\text { equivalent }\end{array}$ & 1994 & 3036.9 & REF & & REF & \\
\hline $\begin{array}{l}\text { Bachelor and } \\
\text { above }\end{array}$ & 51 & 127.9 & 0.61 & $0.46-0.80$ & 0.62 & $0.47-0.82$ \\
\hline \multicolumn{7}{|l|}{ AFQT percentile } \\
\hline $65-99$ & 707 & 1219.7 & 0.87 & $0.77-0.97$ & & \\
\hline $50-64$ & 499 & 745.0 & REF & & & \\
\hline $11-50$ & 832 & 1192.8 & 1.04 & $0.93-1.16$ & & \\
\hline
\end{tabular}

ARMS, Assessment of Recruit Motivation and Strength; BMI, body mass index; AFQT, Armed Forces Qualification Test.

a IRRs adjusted for sex, smoking status and education.
Table 4

Crude and adjusted incidence rate ratios for mental disorder diagnosis among subjects who passed the step test $(\mathrm{N}=8866)$

\begin{tabular}{|c|c|c|c|c|c|c|}
\hline & \multirow{2}{*}{$\begin{array}{l}\text { Number } \\
\text { with mental } \\
\text { disorder } \\
\text { diagnosis }\end{array}$} & \multirow{2}{*}{$\begin{array}{l}1000 \\
\text { person-days }\end{array}$} & \multicolumn{2}{|c|}{ Crude IRR } & \multicolumn{2}{|c|}{ Adjusted $^{\mathrm{a}}$ IRR } \\
\hline & & & Value & $95 \% \mathrm{CI}$ & Value & $95 \% \mathrm{CI}$ \\
\hline \multicolumn{7}{|l|}{$E B F$} \\
\hline No & 1430 & 2433.4 & REF & & REF & \\
\hline Yes & 289 & 346.4 & 1.22 & $1.07-1.40$ & 1.11 & $0.96-1.27$ \\
\hline \multicolumn{7}{|l|}{ Sex } \\
\hline Male & 1249 & 2391.2 & REF & & REF & \\
\hline Female & 430 & 388.6 & 2.12 & $1.90-2.36$ & 2.21 & $1.98-2.47$ \\
\hline \multicolumn{7}{|l|}{ Age (years) } \\
\hline $18-19$ & 782 & 1301.8 & REF & & & \\
\hline $20-24$ & 697 & 1144.0 & 1.01 & $0.92-1.12$ & & \\
\hline$\geq 25$ & 200 & 334.0 & 1.00 & $0.85-1.16$ & & \\
\hline \multicolumn{7}{|l|}{ Smoker } \\
\hline No & 1129 & 2074.1 & REF & & REF & \\
\hline Yes & 530 & 666.2 & 1.46 & $1.32-1.62$ & 1.54 & $1.39-1.71$ \\
\hline \multicolumn{7}{|l|}{ Education } \\
\hline $\begin{array}{l}\text { HS diploma } \\
\text { and } \\
\text { equivalent }\end{array}$ & 1636 & 2661.2 & REF & & REF & \\
\hline $\begin{array}{l}\text { Bachelor } \\
\text { and above }\end{array}$ & 42 & 118.6 & 0.58 & $0.42-0.78$ & 0.58 & $0.42-0.78$ \\
\hline \multicolumn{7}{|c|}{ AFQT percentile } \\
\hline $65-99$ & 583 & 1098.8 & 0.84 & $0.74-0.95$ & & \\
\hline $50-64$ & 415 & 654.2 & REF & & & \\
\hline $11-50$ & 676 & 1021.5 & 1.04 & $0.92-1.18$ & & \\
\hline
\end{tabular}

ARMS, Assessment of Recruit Motivation and Strength; WQ weight qualified; EBF, excess body fat; BMI, body mass index; AFOT, Armed Forces Qualification Test

a IRRs adjusted for sex, smoking status and education.

association was observed in the unadjusted model, when adjusted for covariates no significant association was found for exceeding body fat standards. The null findings for EBF were supported by the lack of any

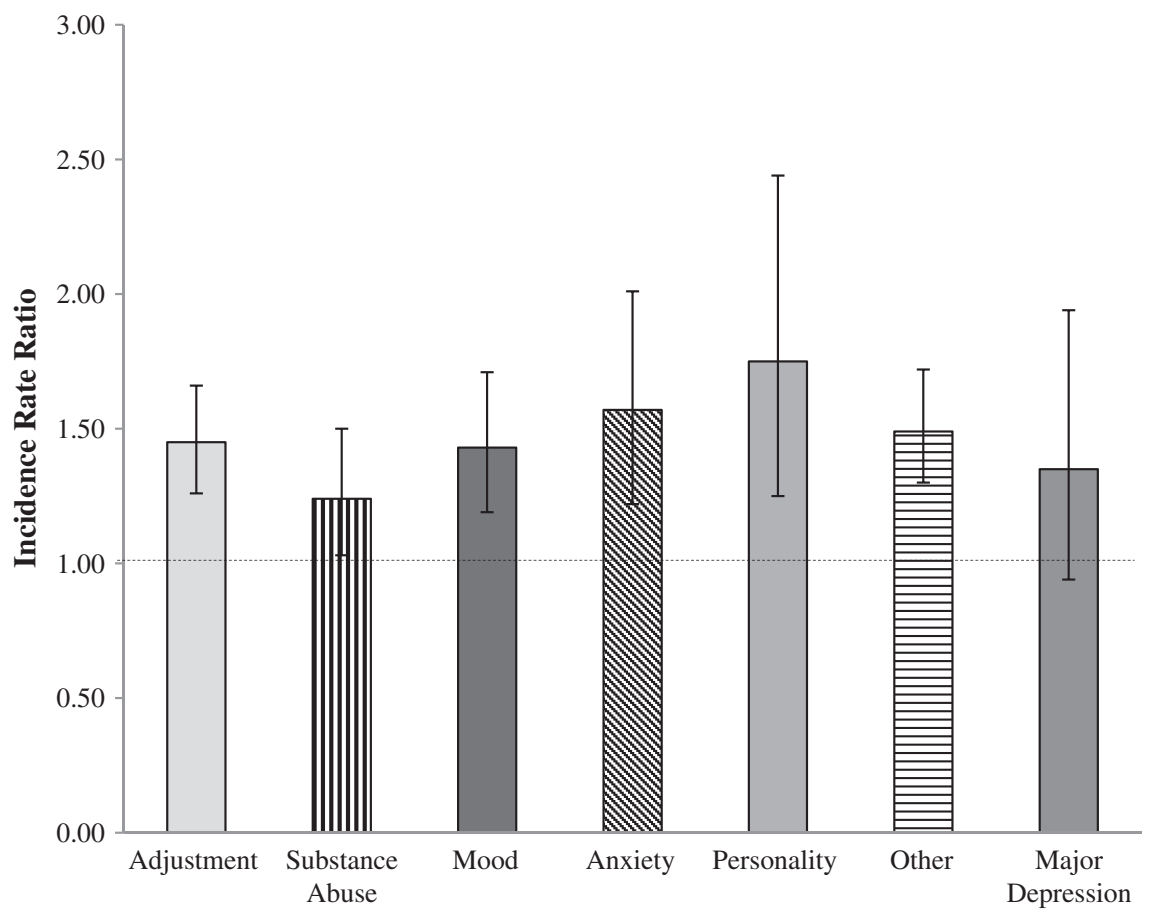

Mental Disorder Category

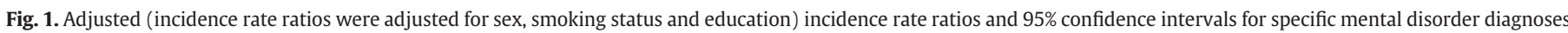
in the first year of service by step test status (ratio: fail/pass). 
association between overweight and obese BMI categories and mental health disorder among those who were weight qualified. The generally null findings between the EBF and FQ and across the range of BMI are encouraging, however, providing evidence that young people who are overweight based on body fat percentage and BMI but who are not morbidly obese are not at increased risk of mental disorders.

Strengths of this study include the prospective cohort design in which fitness and body fat were objectively measured prior to military entrance, the large study population, and robust data captured on a variety of clinical and demographic factors. A potential weakness may be limited generalizability because this study population includes only active duty Army recruits undergoing military training. Army basic training is a unique physically and mentally demanding experience that has no exact analog in civilian life. Thus, the incidence of psychiatric disorders could potentially be higher than in any age-comparable cohort in the civilian population. In addition, no information was available on study subjects' medical or mental disorder diagnoses prior to military service or for those who were not eligible to enlist (i.e., those who exceeded body fat allowances and failed the step test). This study also did not examine self-reported physical activity or exercise, but only directly measured physical fitness at military entrance. A previous study of a subset of the ARMS study population who self-reported leisure and school physical activity on a questionnaire administered as part of the ARMS study found that physical activity was moderately predictive of passing the fitness test (odds of passing ranged from 1.42 to 1.57 comparing weight qualified and exceeds body fat subjects separately by sex) [33]. However, when the activity questionnaire results were included in preliminary analyses for this report, no statistically significant association was found between physical activity and diagnosis of mental disorder. Therefore, self-reported physical activity was not reported in the final analysis.

Although the Army training population may differ in the proportions of some demographic subgroups, it is broadly representative of the young adult civilian population. Military members are generally healthier than age-specific civilians, as all applicants provide a medical history (which specifically inquires about mental health problems) and are given a medical examination prior to entry [25]. Applicants with overt mental health problems or who reported a history of mental disorders generally require a medical waiver prior to entrance into the Army [25]. Nonetheless, the stigma associated with accessing mental health care or the desire to deal with mental illness independent of mental health care may still affect military personnel similar to a civilian population. Interpretation of our findings is facilitated through our multivariable analyses of IRR controlling for sex, smoking status and education, and any limitations due to accessing mental health care are likely to have affected each study cohort similarly. Also, due to lack of morbidly obese study subjects, the null findings between obesity and mental disorder diagnosis may be limited in applicability to the overweight and slightly obese young adult population.

In general, the etiology of mental disorders is poorly understood and assumed to be multifactorial. The mechanism of action for the observed relationship between fitness and mental disorder is not known, but there are at least two potential modes. One could be via brain derived neurotrophic factor (BDNF), a genetically regulated protein that may limit or repair damage caused by stress [42]. Studies have shown higher levels of BDNF are associated with lower risks of some psychiatric disorders [42-44], and there is some evidence that exercise and fitness increase the level of BDNF [42-48]. Another mode could be related to vitamin $D$ levels, which appear to be associated with activity and fitness [49-53], and may also be associated with psychiatric disorders [54-57]. Studies similar in concept to the current work, but which include serial collections of blood for testing may offer the potential to better understand the fitness, exercise, BDNF, vitamin D, and psychiatric disorder hypotheses.
Although exercise may be an important connection between fitness and mental disorders explaining the associations observed in this and other studies, the purpose of this analysis was to assess measured physical fitness as a potential addition to the pre-enlistment physical examination process as a predictor of mental disorder diagnoses early in military training and career. Other findings in this study, specifically that smoking, female sex, and lower educational status are associated with mental disorders, are not of primary interest in these analyses, but are consistent with current medical literature $[1,58-60]$.

More than two-thirds of the U.S. adult population is overweight or obese, and about one-quarter is physically inactive [61]. About half of U.S. adults are diagnosed with a mental disorder within their lifetime, with a 12-month prevalence of approximately $26 \%$ $[1,62]$. Civilian population trends in obesity, inactivity, and mental health directly impact the military's ability to recruit personnel who are fit to serve. Exceeding weight and body fat allowances is the leading cause of disqualification from military service, with psychiatric conditions the third most common [63]. A review of temporal trends in U.S. Army recruits showed that trends differed depending on the physical fitness measure [64]. However, aerobic fitness measured by 1 and 2 mile run times have been declining and body fat percentages among men have increased [64]. Clearly mental disorders, obesity, inactivity and poor physical fitness in the civilian sector pose a significant challenge to the recruitment and sustainment of a healthy and formidable military force. Nonetheless, the impact of fitness, activity and obesity on mental health is not well understood.

\section{Conclusions}

This prospective study of healthy young adults entering the U.S. Army has shown that a simple and easily administered step test is predictive of subsequent psychiatric disorders among weight qualified applicants, and that exceeding weight for height and body fat allowances was not a significant predictor. This study's findings are primarily hypothesis-generating and the fitness test should not be used alone to screen in or out individuals applying for military service. However, a pre-enlistment step test has potential utility to the military as an adjunct part of the medical examination, similar to its use during the ARMS study, to identify military applicants who are likely to succeed in military service. Additional research and evaluation is required to determine if and how such a test could be best utilized. Based on our design and findings, additional studies could be conducted in other populations to determine if similar associations are observed. If so, it may be possible to develop intervention studies to ascertain if improving physical fitness reduces the risk of subsequent mental disorders, particularly among young adults entering into stressful situations.

\section{Competing interest statement}

The views expressed are those of the authors and should not be construed to represent the positions of the Department of the Army or Department of Defense. None of the authors have any associations, financial or otherwise, that may present a conflict of interest.

\section{Acknowledgments}

The authors are grateful for Ms. Janice Kay Gary, Walter Reed Army Institute of Research, Preventive Medicine Branch staff for administrative support in preparation of this manuscript.

This study was funded by the US Army Accession Command. 


\section{References}

[1] Kessler RC, Berglund P, Demler O, Jin R, Merikangas KR, Walters EE. Lifetime prevalence and age-of-onset distributions of DSM-IV disorders in the National Comorbidity Survey Replication. Arch Gen Psychiatry 2005;62:593-602.

[2] Henderson M, Harvey SB, Overland S, Mykletun A, Hotopf M. Work and common psychiatric disorders. J R Soc Med 2011;104:198-207.

[3] Johnson J, Weissman MM, Klerman GL. Service utilization and social morbidity associated with depressive symptoms in the community. JAMA 1992;267:1478-83.

[4] Kessler RC, Frank RG. The impact of psychiatric disorders on work loss days. Psychol Med 1997;27:861-73.

[5] Sanderson K, Andrews G. Common mental disorders in the workforce: recent findings from descriptive and social epidemiology. Can J Psychiatry 2006;51: 63-75.

[6] Armed Forces Health Surveillance Center. Hospitalizations for mental disorders, active component, U.S. Armed Forces, January 2000-December 2009.Medical Surveillance Monthly Report (MSMR), 17; Nov 2010. p. 6-13 [Url: http://www.afhsc. mil/viewMSMR?file=2010/v17_n11.pdf].

[7] Hoge CW, Lesikar SE, Guevara R, Lange J, Brundage JF, Engel CC, et al. Mental disorders among U.S. military personnel in the 1990s: association with high levels of health care utilization and early military attrition. Am J Psychiatry 2002;159: 1576-83.

[8] Garvey Wilson AL, Messer SC, Hoge CW. U.S. military mental health care utilization and attrition prior to the wars in Iraq and Afghanistan. Soc Psychiatry Psychiatr Epidemiol 2009;44:473-81.

[9] Hoge CW, Toboni HE, Messer SC, Bell N, Amoroso P, Orman DT. The occupational burden of mental disorders in the U.S. military: psychiatric hospitalizations, involuntary separations, and disability. Am J Psychiatry 2005;162:585-91.

[10] Army Regulation 600-9: The Army Weight Control Program, November 27, 2006.Washington, DC: Headquarters, Department of the Army; December 12, 2012 [Url: http://www.apd.army.mil/pdffiles/r600_9.pdf].

[11] Paluska SA, Schwenk TL. Physical activity and mental health: current concepts. Sports Med 2000;29:167-80.

[12] Strohle A. Physical activity, exercise, depression and anxiety disorders. J Neural Transm 2009;116:777-84.

[13] Dunn AL, Jewell JS. The effect of exercise on mental health. Curr Sports Med Rep 2010;9:202-7.

[14] Martinsen EW. Physical activity in the prevention and treatment of anxiety and depression. Nord J Psychiatry 2008;62:25-9.

[15] Prince SA, Adamo KB, Hamel ME, Hardt J, Connor Gorber S, Tremblay M. A comparison of direct versus self-report measures for assessing physical activity in adults: a systematic review. Int J Behav Nutr Phys Act 2008;5:56.

[16] Simon GE, Von Korff M, Saunders K, Miglioretti DL, Crane PK, Van Belle G, et al. Association between obesity and psychiatric disorders in the US adult population. Arch Gen Psychiatry 2006;63:824-30.

[17] Mather AA, Cox BJ, Enns MW, Sareen J. Associations of obesity with psychiatric disorders and suicidal behaviors in a nationally representative sample. J Psychosom Res 2009;66:277-85.

[18] Scott KM, McGee MA, Wells JE, Oakley Browne MA. Obesity and mental disorders in the adult general population. J Psychosom Res 2008;64:97-105.

[19] Pickering RP, Goldstein RB, Hasin DS, Blanco C, Smith SM, Huang B, et al. Temporal relationships between overweight and obesity and DSM-IV substance use, mood, and anxiety disorders: results from a prospective study, the National Epidemiologic Survey on Alcohol and Related Conditions. J Clin Psychiatry 2011;72: 1494-502.

[20] Petry NM, Barry D, Pietrzak RH, Wagner JA. Overweight and obesity are associated with psychiatric disorders: results from the national epidemiologic survey on alcohol and related conditions. Psychosom Med 2008;70:288-97.

[21] Roberts RE, Deleger S, Strawbridge WJ, Kaplan GA. Prospective association between obesity and depression: evidence from the Alameda County Study. Int J Obes Relat Metab Disord 2003;27:514-21.

[22] Kasen S, Cohen P, Chen H, Must A. Obesity and psychopathology in women: a three decade prospective study. Int J Obes (Lond) 2008;32:558-66.

[23] Hasler G, Pine DS, Gamma A, Milos G, Ajdacic V, Eich D, et al. The associations between psychopathology and being overweight: a 20-year prospective study. Psychol Med 2004;34:1047-57.

[24] Sanderson K, Patton GC, McKercher C, Dwyer T, Venn AJ. Overweight and obesity in childhood and risk of mental disorder: a 20-year cohort study. Aust N Z J Psychiatry 2011;45:384-92.

[25] Army Regulation 40-501: Standards of Medical Fitness, December 14, 2007. Washington, DC: Headquarters, Department of the Army; December 12, 2012 [Url: http://www.apd.army.mil/pdffiles/r40_501.pdf].

[26] ASVAB. Military.com. http://www.military.com/join-armed-forces/disqualifiersmedical-conditions.html; March 26, 2013.

[27] Niebuhr DW, Scott CT, Li Y, Bedno SA, Han W, Powers TE. Preaccession fitness and body composition as predictors of attrition in U.S. Army recruits. Mil Med 2009;174:695-701.

[28] Cowan DN, Bedno SA, Urban N, Yi B, Niebuhr DW. Musculoskeletal injuries among overweight army trainees: incidence and health care utilization. Occup Med (Lond) 2011:61:247-52.

[29] Bedno SA, Li Y, Han W, Cowan DN, Scott CT, Cavicchia MA, et al. Exertional heat illness among overweight U.S. Army recruits in basic training. Aviat Space Environ Med 2010;81:107-11.

[30] Niebuhr DW, Scott CT, Powers TE, Li Y, Han W, Millikan AM, et al. Assessment of recruit motivation and strength study: preaccession physical fitness assessment predicts early attrition. Mil Med 2008;173:555-62.
[31] Bedno SA, Cowan DN, Urban N, Niebuhr DW. Effect of pre-accession physical fitness on training injuries among US Army recruits. Work 2013;44(4):509-15.

[32] Cowan DN, Bedno SA, Urban N, Lee D, Niebuhr DW. Step test performance and risk of stress fractures among female army trainees. Am J Prev Med 2012;42:620-4.

[33] Gubata ME, Cowan DN, Bedno SA, Urban N, Niebuhr DW. Self-reported physical activity and preaccession fitness testing in U.S. Army applicants. Mil Med 2011;176:922-5.

[34] Sloan AW. The Harvard step test of dynamic fitness. Triangle 1962:5:358-63.

[35] Brouha GA, Graybiel A, Heath C. The step test: a simple method of measuring physical fitness for hard muscular work in adult men. Rev Can Biol 1943;2:86-91.

[36] Montoye HJ. The Harvard step test and work capacity. Rev Can Biol 1953;11: 491-9.

[37] Banerjee PK, Chatterjee S. Harvard step test as a measure of physical fitness in adolescent boys. Indian J Med Res 1984;79:413-7.

[38] Keen EN, Sloan AW. Observations on the Harvard step test. J Appl Physiol 1958;13:241-3.

[39] Sloan AW. A modified Harvard step test for women. J Appl Physiol 1959;14 985-6.

[40] ASVAB. Military.com. http://www.military.com/join-armed-forces/asvab/; June $19,2012$.

[41] Centers for Disease Control and Prevention. Defining overweight and obesity. http://www.cdc.gov/obesity/adult/defining.html; June 19, 2012.

[42] Mata J, Thompson RJ, Gotlib IH. BDNF genotype moderates the relation between physical activity and depressive symptoms. Health Psychol 2010;29:130-3.

[43] Gomez-Pinilla F. The influences of diet and exercise on mental health through hormesis. Ageing Res Rev 2008;7:49-62.

[44] Nagahara AH, Tuszynski MH. Potential therapeutic uses of BDNF in neurological and psychiatric disorders. Nat Rev Drug Discov 2011;10:209-19.

[45] Ferris LT, Williams JS, Shen CL. The effect of acute exercise on serum brain-derived neurotrophic factor levels and cognitive function. Med Sci Sports Exerc 2007;39: 728-34.

[46] Gold SM, Schulz KH, Hartmann S, Mladek M, Lang UE, Hellweg R, et al. Basa serum levels and reactivity of nerve growth factor and brain-derived neurotrophic factor to standardized acute exercise in multiple sclerosis and controls. J Neuroimmunol 2003;138:99-105.

[47] Griffin ÉW, Mullally S, Foley C, Warmington SA, O'Mara SM, Kelly AM. Aerobic exercise improves hippocampal function and increases BDNF in the serum of young adult males. Physiol Behav 2011;104:934-41.

[48] Cho HC, Kim J, Kim S, Son YH, Lee N, Jung SH. The concentrations of serum, plasma and platelet BDNF are all increased by treadmill $\mathrm{VO}_{2 \max }$ performance in healthy college men. Neurosci Lett 2012;519:78-83.

[49] Chomistek AK, Chiuve SE, Jensen MK, Cook NR, Rimm EB. Vigorous physical activity, mediating biomarkers, and risk of myocardial infarction. Med Sci Sports Exerc 2011;43:1884-90.

[50] Ward KA, Das G, Berry JL, Roberts SA, Rawer R, Adams JE, et al. Vitamin D status and muscle function in post-menarchal adolescent girls. J Clin Endocrinol Metab 2009;94:559-63.

[51] Hamilton B. Vitamin D and human skeletal muscle. Scand J Med Sci Sports 2010;20:182-90.

[52] Farrell SW, Willis BL. Cardiorespiratory fitness, adiposity, and serum 25-dihydroxyvitamin D levels in women: the Cooper Center Longitudinal Study. J Womens Health (Larchmt) 2012;21:80-6.

[53] Ardestani A, Parker B, Mathur S, Clarkson P, Pescatello LS, Hoffman HJ, et al. Relation of vitamin D level to maximal oxygen uptake in adults. Am J Cardiol 2011;107:1246-9.

[54] Berk M, Sanders KM, Pasco JA, Jacka FN, Williams LJ, Hayles AL, et al. Vitamin D deficiency may play a role in depression. Med Hypotheses 2007;69:1316-9.

[55] Howland RH. Vitamin D and depression. J Psychosoc Nurs Ment Health Serv 2011;49:15-8.

[56] Ganji V, Milone C, Cody MM, McCarty F, Wang YT. Serum vitamin D concentrations are related to depression in young adult US population: the Third National Health and Nutrition Examination Survey. Int Arch Med 2010;3:29.

[57] Jorde R, Sneve M, Figenschau Y, Svartberg J, Waterloo K. Effects of vitamin D supplementation on symptoms of depression in overweight and obese subjects: randomized double blind trial. J Intern Med 2008 Dec;264:599-609.

[58] Lasser K, Boyd JW, Woolhandler S, Himmelstein DU, McCormick D, Bor DH. Smoking and mental illness - a population-based prevalence study. J Am Med Assoc 2000;284:2606-10.

[59] Tsai J, Edens EL, Rosenheck RA. Nicotine dependence and its risk factors among users of veterans health services, 2008-2009. Prev Chronic Dis 2011;8:A127.

[60] Lawrence D, Mitrou F, Zubrick SR. Smoking and mental illness: results from population surveys in Australia and the United States. BMC Public Health Aug 7 2009;9:285.

[61] Li C, Balluz L, Okoro C, Strine T, Lin J, Town M, et al. Surveillance of certain health behaviors and conditions among states and selected local areas - behavioral risk factor surveillance system, United States, 2009. MMWR Surveill Summ 2011;60: $1-252$.

[62] Kessler RC, Chiu WT, Demler O, Merikangas KR, Walters EE. Prevalence, severity, and comorbidity of 12-month DSM-IV disorders in the National Comorbidity Survey Replication. Arch Gen Psychiatry 2005;62:617-27.

[63] Accession Medical Standards Analysis \& Research Activity (AMSARA). Annual report: Defense Technical Information Center technical report; 2010 [Accession Number: ADA528532, Url: http://handle.dtic.mil/100.2/ADA528532].

[64] Knapik JJ, Sharp MA, Darakjy S, Jones SB, Hauret KG, Jones BH. Temporal changes in the physical fitness of US Army recruits. Sports Med 2006;36:613-34. 